\title{
Kinetic Modeling of Essential Oil Extraction by Hydrodistillation of Xylopia aethiopica (Dunal) A. Rich Fruits from Congo-Brazzaville
}

\author{
Thomas Silou, Jean Bruno Bassiloua, and Rosalie Kama-Niamayoua
}

\section{ABSTRACT}

The extraction kinetics of the essential oil of Xylopia aethiopica (Dunal) A. Rich by hydrodistillation was studied for modeling its process and optimizing its yield. The oils obtained, analyzed by GC/MS, consists mainly of pinenes, sabinene, myrenal, terpinene-4-ol, limonene. Experimental data were fitted into first and second order kinetics for a 2-steps extraction, washing and diffusion, of the phenomenological model, according to the hypothesis used. The essential oil which moves inner vegetable cells by diffusion and is extracted at the surface of the particle by washing with an extraction solvent. When the washing step is instantaneous compared to that of diffusion, the mechanism, which is under diffusion control, admits first order. Considering both washing and diffusion steps, kinetic order became 2 , in agreement with the Peleg model. The Monod and Langmuir models also fitted experimental data. All these models validated by the experimental data with determination coefficients $\mathbf{R}^{2}>0.96$ can be used for optimizing the extraction of the essential oil of Xylopia aethiopica (Dunal) A. Rich.

Keywords: Kinetics, essential oil, Xylopia aethiopia, Congo-Brazzaville.
Published Online: June 30, 2021

ISSN: 2684-5199

DOI: 10.24018 / ejbio.2021.2.3.120

\section{Thomas Silou*}

PhD program (T2A) Food Chemistry and Technology, Faculty of Sciences and Techniques, Marien Ngouabi University (UMNG), Higher School of Technology "Les Cataractes", Congo.

(e-mail: thsilou@ ${ }^{@}$ ahoo.fr)

Jean Bruno Bassiloua

PhD program (T2A) Food Chemistry and Technology, Faculty of Sciences and Techniques, Marien Ngouabi University (UMNG), Congo.

(e-mail: bassilouajeanbruno@yahoo.fr) Rosalie Kama-Niamayoua

Higher School of Technology "Les

Cataractes", Congo.

(e-mail: presfawe ${ }^{@}$ yahoo.fr)

*Corresponding Author

\section{INTRODUCTION}

The geographic area of the genus Xylopia extends from Senegal to South Sudan through the Sahel to the East and to Angola, South Africa and Mozambique to the South. It colonizes the lowlands of the tropical rain forest, with a very high concentration in the Congo Basin: Cameroon and Gabon host 27 of 45 african species [1], [2]. There are 160 to 180 species of Xylopia worldwide. The revision of 45 African species of Xylopia due to Johnson and Murray signals 4 new species and brings out new subdivisions.

It is a multipurpose tree. However, its highly "spicy" seeds make it a spice and condiment that is highly prized throughout tropical Africa [3]-[6]. In traditional medicine, Xylopia aethiopica is used in the treatment of scabies [1], [5], [7], [8]. In some countries like Benin, it is threatened with extinction due to anthropogenic pressures that it suffers because of its multiple uses: medicinal uses (more than 60 $\%$ ), magico-religious uses (22\%), firewood, construction wood and food (18\%) [9], [10]. To guarantee its sustainability, a program to afforest the coastal savannah of Pointe Noire in Congo Brazzaville was undertaken by planting Xylopia aethiopica for the production of medicinal essential oil in addition to firewood [11]. Extraction optimization has been studied very little and no work on kinetic modeling has been found in the literature. These are two important steps on the way to scale-up the production of this essential oil. We present here first results on the kinetic modeling of the extraction of the essential oil of Xylopia aethiopica fruits from Congo-Brazzaville.

\section{MATERIAL AND METHODS}

\section{A. Botanical description of Xylopia aethiopia}

According to the classification Angiosperm Phylogeny Group (APG) III [12], the species Xylopia aethiopica belongs to the clades Angiosperms / Magnoliidae, in the order of Magnoliales, to the family Annonaceae, to the genus Xylopia, to the species aethiopica. It accepts as synonyms: Unona aethiopica Dunal, Uvaria aethiopica (Dunal) A. Rich, Habzelia aethiopica (Dunal) Kuntze, Xylopia eminii Engler, Xylopia dekeyzeriana De Wild, Xylopia gilletii De Wild. Xylopia aethiopica, commonly known as "African peeper" is a tree $15-30 \mathrm{~m}$ high and $60-75 \mathrm{~cm}$ in diameter, growing either on rivers or in swamps. It is straight tree. Its leaves are oblong-lanceolate, obtuse, or rounded at the base, acuminate, glabrous, glaucous below, 4 to $10 \mathrm{~cm}$ in length, 2 to $4 \mathrm{~cm}$ in width. Its scented flowers are white-greenish. Its cylindrical 
linear fruits are arranged in 12 to 20 bacciform capsules of dark green color when ripe. Its seeds ( 4 to 12 per pod) form a single row. They are ellipsoidal in shape (5.0-6.0 in length; $3.4-3.7 \mathrm{~mm}$ in width and $2.5-3.1 \mathrm{~mm}$ in thickness), and are dark brown to black [2], [13].

The fruits of $X$. aethiopica studied were collected wild in the Youbi forest, $\left(4^{\circ} 0^{\prime} 00^{\prime}-4^{\circ} 30^{\prime} 00^{\prime}\right.$ latitudes South and $11^{\circ} 30^{\prime} 00^{\prime}$ ' and $12^{\circ} 0$ ' $00^{\prime}$ 'longitudes) at $100 \mathrm{~km}$ north of the town of Pointe-Noire (Congo-Brazzaville).

\section{B. Essential oil extraction by hydrodistillation}

The essential oils were obtained by hydrodistillation. Water and plant material (300 $\mathrm{g}$ of dried fruits $\left(\mathrm{m}_{1}\right.$, in dry basis-db-) were placed in a $500 \mathrm{~mL}$ round bottomed flask and boiled for $4 \mathrm{~h}$. The organic phase of the condensate was separated from the aqueous phase with diethyl ether and dried over sodium sulphate. The essential oil was recovered after evaporation of the solvent $\left(\mathrm{m}_{2}\right)$ and extraction yield is given by:

$$
\mathrm{Y}(\%) \mathrm{db}=\left(\mathrm{m}_{2} / \mathrm{m}_{1}\right) 100
$$

\section{Chromatographic Analysis}

GC analyses was performed on a Hewlett-Packard 6890 equipped with a split/splitness injector $\left(280{ }^{\circ} \mathrm{C}\right.$, split ratio 1:10), using DB-5 column (30 m $\times 0.25 \mathrm{~mm}$, df: $0,25 \mu \mathrm{m})$. The temperature program was $50{ }^{\circ} \mathrm{C}(5 \mathrm{~min})$ rising to $300{ }^{\circ} \mathrm{C}$ at rate of $5{ }^{\circ} \mathrm{C} / \mathrm{min}$. Injector and detector temperature was $280^{\circ} \mathrm{C}$. Helium was used as carrier gas at a flow rate 1 $\mathrm{mL} / \mathrm{min}$. The injection of the sample consisted of $1.0 \mu \mathrm{L}$ of oil diluted to $10 \% \mathrm{v} / \mathrm{v}$ with acetone.
GC/MS was performed on a Hewlett-Packard 5973/6890 system operating in EI mode $(70 \mathrm{eV})$, equipped with a split/splitness injector $\left(280^{\circ} \mathrm{C}\right.$, split ratio 1:20), using DB-5 column $(30 \mathrm{~m} \times 0.25 \mathrm{~mm}$, df: $0,25 \mu \mathrm{m})$. The temperature program was $50^{\circ} \mathrm{C}(5 \mathrm{~min})$ rising to $300{ }^{\circ} \mathrm{C}$ at rate of $5^{\circ} \mathrm{C} / \mathrm{min}$. Injector and detector temperature was $280^{\circ} \mathrm{C}$. Helium was used as carrier gas at a flow rate $1 \mathrm{~mL} / \mathrm{min}$. The identification was carried out by calculating retention indices and comparing mass spectra with those in data banks [14], [15].

\section{Kinetic Modeling}

The kinetic modeling of the metabolite extraction from a solid plant matrix is active field of research [16]-[19]. It is an important step to scale-up metabolite extraction yields. The models used are based on physical laws (formal kinetics, Fick's diffusion law) or on empirical laws [17], [20]-[22].

The transposition to the chemical kinetic formalism of the physical extraction of essential oil is done (i) by assimilating the essential oil content to the concentration $\mathrm{C}$, with $\mathrm{C}_{0}$ the concentration at the initial time $t=0$. (ii) by defining, $V_{0}$, as the quantity of essential oil remained in plant material at the initial time $(\mathrm{t}=0) ; \mathrm{V}$, the amount of essential oil extracted at time $\mathrm{t} ;\left(\mathrm{V}_{0}-\mathrm{V}\right)$ then becomes the amount of essential oil remaining in plant material at time $\mathrm{t}$ [21], [23]. If $\mathrm{y}=\left(\mathrm{V}_{0^{-}}\right.$ $\mathrm{V}) / \mathrm{V}_{0}$, is the degree of extraction, the integration of first order chemical kinetic leads to (1):

$$
\ln (1 /(1-\mathrm{y}))=\mathrm{kt}
$$

Table I summarizes the main models used in the study of metabolite extraction from plant matrices.

\begin{tabular}{|c|c|c|}
\hline Authors [ref.] & Models & Term meaning \\
\hline $\begin{array}{l}\text { Ameneghawon et al. [23] } \\
\quad \text { Thanh et al. }[24]\end{array}$ & $\begin{array}{c}\text { First order kinetics } \\
\mathrm{dC}_{\mathrm{t}} / \mathrm{dt}=\mathrm{k}\left(\mathrm{C}_{0}-\mathrm{C}\right) \\
\ln \left(\mathrm{C} / \mathrm{C}_{0}\right)=-\mathrm{kt} ; \mathrm{t}_{1 / 2}=0,693 / \mathrm{k} \\
\ln [1 /(1-\mathrm{y}(\mathrm{t})]=\mathrm{kt}\end{array}$ & $\begin{array}{l}\mathrm{C}_{\mathrm{t}} \text {, concentration or mass of oil in plant matrix at time } \mathrm{t} ; \mathrm{C}_{0} \text {, initial } \\
\text { concentration or mass of oil in plant matrix; } \\
\mathrm{k} \text {, first order kinetic constant }\left(\mathrm{t}^{-1}\right) ; \mathrm{y}=\left(\mathrm{C}_{0}-\mathrm{C}\right) / \mathrm{C}_{0} \text { : extracted } \mathrm{EO} \text { ratio }\end{array}$ \\
\hline Sepidar et al. [25] & $\begin{array}{c}\text { Second order kinetics } \\
\mathrm{dC}_{\mathrm{t}} / \mathrm{dt}=\mathrm{k}\left(\mathrm{C}_{\mathrm{s}}-\mathrm{C}_{\mathrm{t}}\right)^{2} \\
\left(\mathrm{C}_{\mathrm{t}}=\mathrm{C}_{\mathrm{s}}^{2} \mathrm{kt}\right) /\left(1+\mathrm{C}_{\mathrm{s}} \mathrm{kt}\right) \\
\left(1 / \mathrm{C}_{\mathrm{t}}\right)-\left(1 / \mathrm{C}_{\mathrm{s}}\right)=\mathrm{kt} \\
\mathrm{t} / \mathrm{C}_{\mathrm{t}}=1 /\left(\mathrm{kC}_{\mathrm{s}}^{2}\right)+\mathrm{t} / \mathrm{C}_{\mathrm{s}}\end{array}$ & $\begin{array}{l}\mathrm{C}_{\mathrm{t}} \text {, concentration of extracted oil at time t }\left(\mathrm{g} \cdot \mathrm{L}^{-1}\right) \text {; } \\
\mathrm{C}_{\mathrm{s}} \text {, concentration of extracted oil at saturation }\left(\mathrm{g} \cdot \mathrm{L}^{-1}\right) \text {; } \\
\mathrm{k} \text {, second order kinetic constant }\left(\mathrm{gL}^{-1} \mathrm{~min}^{-1}\right) \text {; } \\
\mathrm{h}=\mathrm{kC}_{\mathrm{s}}^{2} \text { : initial extraction rate }\left(\mathrm{gL}^{-1} \mathrm{~min}^{-1}\right) \text {. }\end{array}$ \\
\hline $\begin{array}{l}\text { So and Macdonald } \\
{[26]}\end{array}$ & 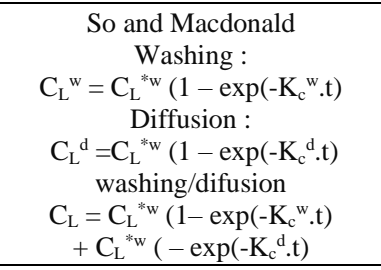 & $\begin{array}{l}\mathrm{C}_{\mathrm{L}} \text { : concentration of extracted oil; } \mathrm{C}_{\mathrm{L}}{ }^{\mathrm{w}} \text { : concentration of extracted oil } \\
\text { (washing step) } ; \mathrm{C}_{\mathrm{L}}{ }^{\mathrm{d}} \text { : concentration of extracted oil (diffusion step) } \mathrm{K}_{\mathrm{c}}{ }^{\mathrm{w}} \text { : } \\
\text { kinetic constant (washing step); } \mathrm{K}_{\mathrm{c}}{ }^{\mathrm{d}} \text { : kinetic constant(diffusion step) }\end{array}$ \\
\hline $\begin{array}{c}\text { Milojevic et al. } \\
\text { [17], [18] } \\
\text { Sovova and Aleksovski [20] }\end{array}$ & $\begin{array}{c}\text { Milojevic } \\
\mathrm{q}_{\mathrm{t}} / \mathrm{q}_{\infty}=f \exp \left(-\mathrm{k}_{1} \mathrm{t}\right) \\
+(1-\mathrm{f}) \exp \left(-\mathrm{k}_{2} \mathrm{t}\right) \\
\end{array}$ & $\begin{array}{l}\mathrm{q}_{\mathrm{p}} \text { quantity of EO in plant matrix at time } \mathrm{t} ; \mathrm{q}_{\infty} \text { quantity of EO in plant matrix } \\
\text { at time } \mathrm{t}_{\infty} ; \mathrm{k}_{1} \text { et } \mathrm{k}_{2}: \text { kinetic constants (washing and diffusion) } ; f: \text { fraction } \\
\text { extracted by washing; } 1-f: \text { fraction extracted by diffusion. }\end{array}$ \\
\hline $\begin{array}{l}\text { Mejri et al. } \\
{[22]}\end{array}$ & $\begin{array}{c}\text { Monod } \\
\mathrm{Y}_{\mathrm{t}}=\mathrm{Y}_{\max }\left[1 /\left(\mathrm{K}_{\mathrm{m}}+\mathrm{t}\right)\right] \\
1 / \mathrm{Y}_{\mathrm{t}}=\left(\mathrm{K}_{\mathrm{m}} / \mathrm{Y}_{\max }\right)(1 / \mathrm{t})+\left(1 / \mathrm{Y}_{\max }\right)\end{array}$ & $\begin{array}{l}Y_{\mathrm{t}} \text { : yeild of extracted oil at time } \mathrm{t}(\mathrm{g} / 100 \mathrm{~g}) ; \mathrm{Y}_{\max } \text { yeild at time } \mathrm{t}_{\infty}, \mathrm{Y}_{\max } / \mathrm{K}_{\mathrm{m}} \text { : } \\
\text { slope of straight line, } \mathrm{K}_{\mathrm{m}} \text { : Monod equation parameter. }\end{array}$ \\
\hline Babu and Singh [27] & $\begin{array}{c}\text { Langmuir } \\
\mathrm{Y}_{\mathrm{t}}=\mathrm{Y}_{\max } \mathrm{t} /(\mathrm{b}+\mathrm{t}) \\
1 / \mathrm{Y}_{\mathrm{t}}=\left(\mathrm{b} / \mathrm{Y}_{\max }\right)(1 / \mathrm{t})+1 / \mathrm{Y}_{\max }\end{array}$ & $\begin{array}{l}\mathrm{Y}_{\mathrm{t}} \text { : yeild of extracted oil at time } \mathrm{t}(\mathrm{g} / 100 \mathrm{~g}) ; \mathrm{Y}_{\max } \text { : yeild at time } \mathrm{t}_{\infty}, \mathrm{b} / \mathrm{Y}_{\max }= \\
\text { slope of straight line; } 1 / \mathrm{Y}_{\max } \text {, ordinate at the origin. }\end{array}$ \\
\hline $\begin{array}{l}\text { Bucic-Kojic et al., [16] } \\
\text { Peleg [21] } \\
\text { Shafaei et al. } \\
\text { [28] }\end{array}$ & $\begin{array}{c}\text { Peleg } \\
\mathrm{C}_{\mathrm{t}}=\mathrm{C}_{0} \pm \mathrm{t} /\left(\mathrm{k}_{1}+\mathrm{K}_{2} \mathrm{t}\right) \\
\mathrm{t} / \mathrm{C}_{\mathrm{t}}=\mathrm{K}_{1}+\mathrm{K}_{2} \mathrm{t} \\
\mathrm{k}=\mathrm{K}_{2} / \mathrm{K}_{1}\end{array}$ & $\begin{array}{l}\mathrm{C}_{\mathrm{t}}: \text { mass of extracted } \mathrm{EO} \text { at time } \mathrm{t}\left(\mathrm{m}_{\mathrm{t}}\right) ; \mathrm{C}_{\infty}: \text { mass of extracted } \mathrm{EO} \text { at } \mathrm{t}_{\infty}\left(\mathrm{m}_{\infty}\right) ; \\
\mathrm{C}_{0}=0 \text { : the mass of extracted } \mathrm{EO} \text { at } \mathrm{t}=0 ; \mathrm{K}_{1} \text { : kinetic extraction constant } \\
(\text { second order: } \\
\left.\mathrm{C}^{-1} \mathrm{t}\right) ; \mathrm{K}_{2} \text {, extraction capacity constant } \\
\left(\mathrm{C}^{-1}\right) ; \text { hydrodistillation kinetic constant } \mathrm{k}\left(\mathrm{t}^{-1}\right)\end{array}$ \\
\hline
\end{tabular}

TABLE I: OVERVIEW OF THE MAIN MODELS USED IN THE STUDY OF METABOLITE EXTRACTION FROM Plant MATRICES 
The models most found in the literature are based on the phenomenological approach assumptions [26], [29], summarized in following seven points (Table I) : (i) Plant particles are considered to have properties such as shape, size and contain the initial essential oil [18]; (ii) The concentration gradients in the fluid phase develop at scales greater than the size of the particles; (iii) The solvent flow rate is uniformly distributed in each section of the extractor [30]; (iv) Part of the essential oil is located on the outer surfaces of the plant particles, $\mathrm{f}$, and the rest is evenly distributed inside the plant particles (1-f); (v) The essential oil is considered to be a single component; (vi) The effective diffusion coefficient through plant particles is constant, and (vii) There is no resistance to essential oil mass transfer from the outer surfaces of plant particles [18].

One simple order kinetic (pseudo first order kinetics, Table I) and 3 empirical models (Sovova-Milojevic, Peleg, Monod models, Table I) were tested here for the essential oil extraction of Xylopia aethiopica fruits.

\section{RESULTS AND DISCUSSION}

\section{A. Content and Composition of the Essential Oil of Fruits}

Only the fruits have a significant essential oil content in Xylopia aethiopica (2-8 \%), the leaves come in second position with contents of $0.05-0.30 \%$ and the bark, in third position (0.01-0.07\%) [11].

Table II shows chemical composition of the studied sample from Congo Brazzaville.

It is a hydrocarbon monoterpenic oil consisting mainly of $\alpha$ and $\beta$ pinenes, sabinene, myrtenal, terpinene-4-ol, limonene. These six major constituents, which represent more than $75 \%$ of the total oil, are followed by around fifty minor constituents (0.10-0.50\%) giving to the chromatogram a high qualitative complexity. The 55 constituents identified by their retention indices and their mass spectra are distributed in 19 hydrocarbon monoterpenes, 27 oxygenated monoterpenes, 2 hydrocarbon sesquiterpenes and 6 oxygenated sesquiterpenes. The only sequiterpene present at more than 1 $>\%$ is isospathulenol $(1.35 \%)$. The studied sample from Congo-Brazzaville belongs to the pinene/sabinene chemotype. Many works, carried out on qualitative and quantitative analysis across Tropical Africa indicate that the essential oils of Xylopia aethiopica are very largely constituted of hydrocarbon monoterpenes represented by $\beta$ pinene (37.0-40.5\% [31]; 12-42\% [32]; 18.3\%) [33]); sabinene: $36.0 \%$ [34]. Germacrene D is the most abundant sesquiterpene and the oxygenated compounds identified are mainly 1,8-cineole and terpinen-4-ol. One essential oil sample from Egypt studied by Karawya et al. [35] consists mainly of oxygenated compounds: $23.4 \%$ of terpinen-4-ol, $16.3 \%$ of 1,8 -cineole and $11.1 \%$ of $\alpha$-terpineol [36], [37]. The Xylopia aethiopica fruits from Nigeria allowed the isolation and characterization for the first time of a fairly rare sesquiterpene ketone : Zerumbone $(4.0 \%)$, in addition to the constituents more commonly found in essential oils: $\beta$ santalol $(14.5 \%)$, $\alpha$-cadinol $(13.0 \%)$, benzyl benzoate and dodecanoic acid $(10.0 \%)$ [38].
TABLE II: CHEMICAL COMPOSITION OF THE STUDIED SAMPLE FROM CONGO BRAZZAVILlE

\begin{tabular}{|c|c|c|c|c|}
\hline RT & $\mathrm{RI}_{\text {calc }}$ & $\mathrm{RI}_{\mathrm{Lit}}$ & Constituents & Content $(\%)$ \\
\hline 5.714 & 919 & 924 & alpha thujene & 0.40 \\
\hline 5.863 & 926 & 932 & alpa pinene & 8.24 \\
\hline 6.182 & 943 & 946 & camphene & 0.24 \\
\hline 6.669 & 967 & 969 & sabinene & 35.84 \\
\hline 6.758 & 972 & 974 & béta pinene & 28.65 \\
\hline 6.953 & 982 & 988 & myrcene & 0.32 \\
\hline 7.214 & 995 & 1003 & mentha-1(7),8-diene & 0.09 \\
\hline 7.455 & 1008 & 1014 & alpha terpiene & 0.16 \\
\hline 7.599 & 1016 & 1029 & p-cymene & 1.29 \\
\hline 7.679 & 1021 & 1024 & limonene & 1.13 \\
\hline 7.708 & 1022 & 1025 & beta phellandrene & 0.51 \\
\hline 7.742 & 1024 & 1026 & 1,8-cineole & 0.69 \\
\hline 7.983 & 1038 & 1044 & (E)-beta-ocimene & 0.12 \\
\hline 8.190 & 1050 & 1054 & gamma terpinene & 0.46 \\
\hline 8.411 & 1062 & 1065 & cis sabinene hydrate & 0.14 \\
\hline 8.649 & 1076 & 1086 & terpinolène & 0.09 \\
\hline 8.898 & 1090 & 1095 & linalol & 0.48 \\
\hline 8.930 & 1092 & 1098 & trans sabinene hydrate & 0.15 \\
\hline 9.313 & 1117 & 1118 & cis para-Menth-2-en-1-ol & 0.12 \\
\hline 9.348 & 1119 & 1122 & alpha campholenal & 0.09 \\
\hline 9.554 & 1134 & 1135 & nopinone & 0.49 \\
\hline 9.586 & 1136 & 1135 & trans pinocarveol & 2.97 \\
\hline 9.651 & 1141 & 1140 & trans verbenone & 0.69 \\
\hline 9.844 & 1155 & 1154 & sabinacetone & 0.50 \\
\hline 9.917 & 1160 & 1160 & pinocarvone & 0.12 \\
\hline 10.017 & 1167 & na & sabinol & 0.30 \\
\hline 10.201 & 1180 & 1174 & terpinene-4-ol & 3.16 \\
\hline 10.234 & 1182 & 1182 & thuj-3-èn-10-al & 0.17 \\
\hline 10.299 & 1187 & 1183 & cryptone & 0.55 \\
\hline 10.360 & 1191 & 1194 & myrtenol & 0.42 \\
\hline 10.432 & 1197 & 1195 & myrtenal & 4.37 \\
\hline 10.608 & 1209 & 1204 & verbenone & 0.32 \\
\hline 10.755 & 1219 & na & verbenol & 0.22 \\
\hline 11.112 & 1244 & 1238 & cuminal & 0.36 \\
\hline 11.230 & 1253 & na & myrtényle formiate & 0.19 \\
\hline 11.620 & 1280 & na & phellandral & 0.19 \\
\hline 11.698 & 1285 & 1287 & bornyle acetate & 0.11 \\
\hline 11.792 & 1292 & 1292 & para-cymen-7-ol & 0.41 \\
\hline 11.901 & 1300 & 1294 & perillic alcohol & 0.12 \\
\hline 12.074 & 1313 & 1314 & 4-hydroxy-cryptenone & 0.13 \\
\hline 12.932 & 1379 & 1374 & alpha copaene & 0.31 \\
\hline 13.089 & 1391 & 1387 & $\begin{array}{c}\text { beta cubebene }+ \text { beta } \\
\text { elemene }\end{array}$ & 0.21 \\
\hline 13.603 & 1431 & 1434 & gamma elemene & 0.09 \\
\hline 14.272 & 1485 & 1484 & germacrene-D & 0.27 \\
\hline 15.147 & 1559 & na & epitorilenol & 0.29 \\
\hline 15.207 & 1564 & 1559 & germacrene-B & 0.11 \\
\hline 15.484 & 1588 & 1582 & caryophyllene oxyde & 0.52 \\
\hline 15.602 & 1598 & na & salvial-4(14)-en-1-one & 0.14 \\
\hline 15.850 & 1620 & na & torilenol & 0.24 \\
\hline 15.982 & 1632 & na & isospathulenol & 1.35 \\
\hline 16.683 & 1694 & 1700 & amorpha-4,9-dien-2-ol & 0.13 \\
\hline 19.207 & 1940 & 1905 & isopiramadiene & 0.51 \\
\hline 19.967 & 2019 & 1997 & manoyle oxyde & 0.33 \\
\hline \multirow[t]{2}{*}{20.274} & 2052 & 2034 & kaurene & 0.10 \\
\hline & & & Total & 99.60 \\
\hline
\end{tabular}

na: not available.

\section{B. Kinetic Modeling of the fruit Essential Oil Extraction of Xylopia aethiopica}

Table III gathers the data on the variation of the yield versus the extraction time as well as the data necessary to test the models studied. 
TABLE III: DATA FOR TESTING MODELS USED IN ESSENTIAL OIL EXTRACTION OF XYLOPIA AETHIOPICA FRUIT FROM CONGO-BRAZZAVILLE

\begin{tabular}{ccccccccccc}
\hline $\mathrm{t}(\mathrm{min})$ & 0 & 15 & 30 & 45 & 60 & 75 & 90 & 105 & 150 & 165 \\
\hline $1 / \mathrm{t}$ & - & 0.067 & 0.033 & 0.022 & 0.017 & 0.013 & 0.011 & 0.01 & 0.007 & 0.006 \\
$\mathrm{Y}_{\mathrm{t}}$ & 0 & 1.85 & 2.31 & 2.57 & 2.77 & 2.92 & 2.97 & 2.99 & $\mathbf{3 . 0 1}$ & $\mathbf{3 . 0 1}$ \\
$1 / \mathrm{Y}_{\mathrm{t}}$ & & 0.54 & 0.43 & 0.39 & 0.36 & 0.34 & 0.34 & 0.33 & 0.33 & 0.33 \\
$\mathrm{y}_{\mathrm{t}}=\mathrm{Y}_{\mathrm{t}} / \mathrm{Y}_{\infty}$ & 0.00 & 0.61 & 0.77 & 0.86 & 0.92 & 0.97 & 0.99 & 1.00 & 1.00 & 1.00 \\
$\ln \left[1 /\left(1-\mathrm{y}_{\mathrm{t}}\right)\right]$ & 0.00 & 0.94 & 1.47 & 1.97 & 2.81 & 3.51 & 4.51 & - & - & - \\
$\mathrm{t} / \mathrm{Y}_{\mathrm{t}}$ & - & 8.11 & 13 & 17.51 & 21.66 & 25.68 & 30.3 & 35.12 & 49.83 & 54.82 \\
$\mathrm{t} / \mathrm{y}_{\mathrm{t}}$ & - & 24.69 & 38.96 & 52.33 & 62.22 & 77.32 & 90.91 & 105.00 & 150.00 & 165.00 \\
\hline
\end{tabular}

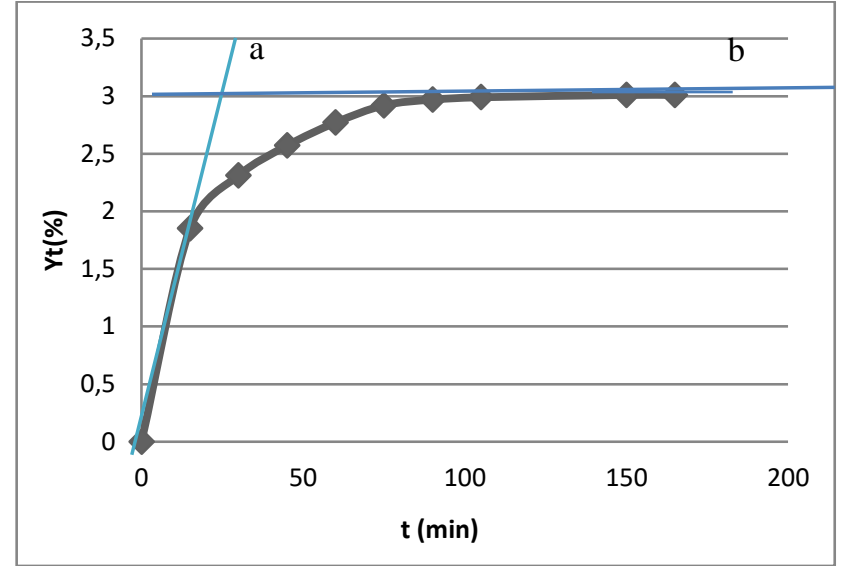

Fig. 1. Variations of extraction yield versus extraction time with Xylopia fruit essential oil.

\section{Test of pseudo first order model}

According to Sovova-Milojevic model, the two-step extraction process leads to:

$$
\mathrm{q}_{\mathrm{t}} / \mathrm{q}_{\infty}=f \exp \left(-\mathrm{k}_{1} \mathrm{t}\right)+(1-\mathrm{f}) \exp \left(-\mathrm{k}_{2} \mathrm{t}\right)
$$

In no washing step assumption, the process is controlled by diffusion step and leads to:

$$
\mathrm{q}_{\mathrm{t}} / \mathrm{q}_{\infty}=1-\exp \left(-\mathrm{k}_{2} \mathrm{t}\right)
$$

dealing to following linear form:

$$
\ln \left(1 /(1-\mathrm{y})=\mathrm{k}_{2} \mathrm{t}\right.
$$

with $y=Y_{t} / Y_{\infty}$

The deviation at the origin of the validation line reflects the existence of a very rapid washing step prior to that of diffusion.

The slope of the straight line $\left(\mathrm{R}^{2}=0.9908\right)$ is a pseudo first order constant : $\mathrm{k}=0,0476 \mathrm{~min}^{-1}$ (Fig. 2). This constant should be compared with those relating to the extraction of Ocimum basilicum $\mathrm{k}=0.0328-0.0741 \mathrm{~min}^{-1}, \mathrm{R}^{2}=0.9359-0.9670$ [39] ; $\mathrm{k}=0.118 \mathrm{~min}^{-1}, \mathrm{R}^{2}=0.99$ [19]; the extraction of Cymbopogon winteranius: $\mathrm{k}=0.047 \mathrm{~min}-1, \mathrm{R}^{2}=0.99$ [19]; the extraction of Cymbopogon citratus : $\mathrm{k}=0.074-0.090 \mathrm{~min}^{-1}$ [18]; the extraction of Cymbopogon flexuosus, $\mathrm{k}=0.025 \mathrm{~min}^{-1}$, $\mathrm{R}^{2}=0.99$ [40]; Curcuma mangga $\mathrm{k}=0.962 \mathrm{~h}^{-1}, \mathrm{R}^{2}=0.969$ [41]. Its value is of the same magnitude $\left(0.010-0.090 \mathrm{~min}^{-1}\right)$ as those of cymbopogons and Ocimum basilicum found in the literature with a very good coefficient of determination $\left(\mathrm{R}^{2}=0.97-0.99\right)$.

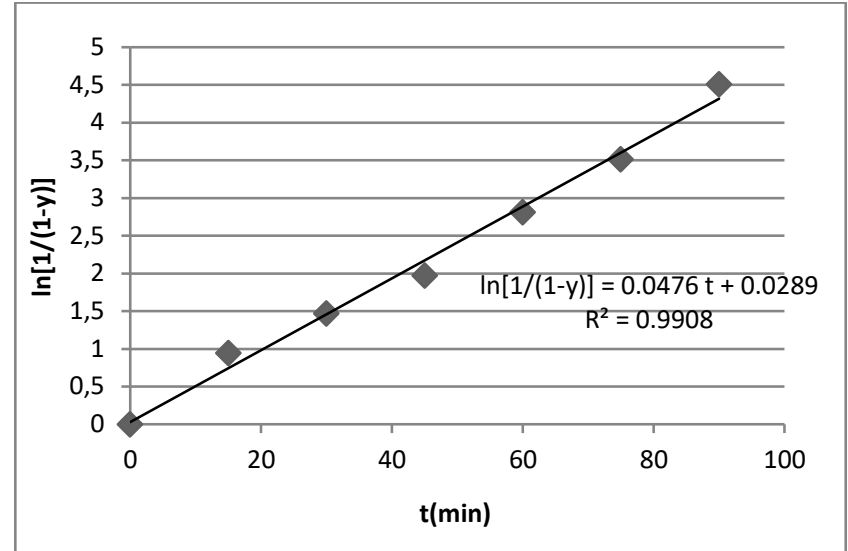

Fig. 2: Validation of the first order test for Xylopia aethipica essential oil extraction (Moljevic Model).

\section{Test of Peleg-Bucic model}

The curve $\mathrm{Y}_{\mathrm{t}}=\mathrm{f}(\mathrm{t})$ (figure 1 ) is similar to that of moisture sorption by flour studied by Paleg [21]. This similarity has led a number of authors to apply Peleg's model to desorption metabolites of plant matrices under kinetic control. For the extraction of essential oil from the fruits of Xylopia aethiopica the validation curve of the Peleg model is a straight line noted $t / Y_{t}=0,309 t+3,214$ with a coefficient of determination $\mathrm{R}^{2}=0.9989$. It leads to the two parameters of the model: the ordinate intercept $\mathrm{K}_{1}=3,214 \mathrm{~min} . \%^{-1}$, the kinetic constant of Peleg and the slope of the line $\mathrm{K}_{2}=0,309$ $\%^{-1}$, the capacity constant of extraction of Peleg.

We deduce the kinetic constant at the initial time $\mathrm{B}_{0}=$ $1 / \mathrm{K}_{1}=0.3111 \% \mathrm{~min}^{-1}$, content at equilibrium (end of the extraction): $\mathrm{C}_{\mathrm{e}}=1 / 0.309=3.24 \%$ and hydrodistillation kinetic constant $\mathrm{k}=\mathrm{K}_{1} / \mathrm{K}_{2}=0.0961 \mathrm{~min}^{-1}$. The value of these two constants is of the same order of magnitude as for those of the extraction of essential oil from the leaves of Ocimum basilicum: $\mathrm{K}_{1}=1.8398-2.7007$ min. $\%^{-1}$ and $\mathrm{K}_{2}=0.3406-$ $0.4990 \%{ }^{-1}$ with $\mathrm{R}^{2}=0.99-1.00$ [39] and Cymbopogon winteranius: $\mathrm{K}_{1}=19.09 \mathrm{~min} .\left(\mathrm{g} / \mathrm{g}^{-1}\right)$ and $\mathrm{K}_{2}=0.0301 \%$ [42].

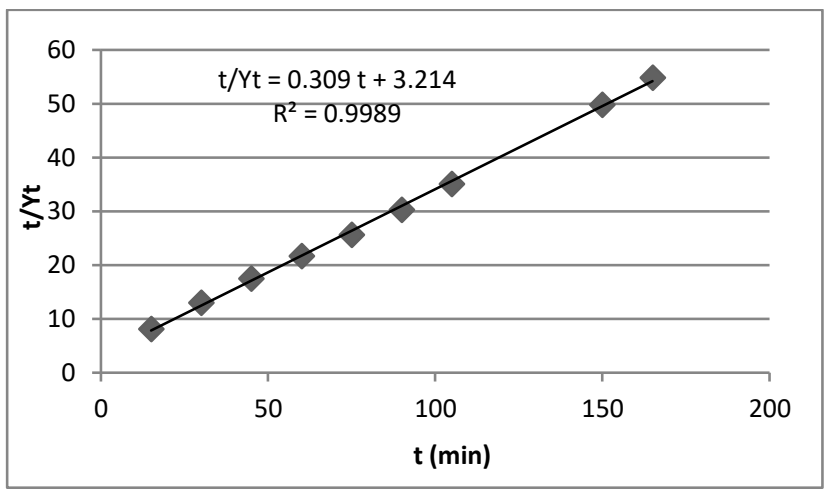

Fig. 3. Peleg model test line for extraction essential oil from the fruits of Xylopia aethiopica. 


\section{Test of Monod and Langmuir models}

These two models are validated by the same linearized equation of $1 / Y_{t}=f(1 / t)$. Monod's model, inspired by Michaelis enzymatic kinetics leads to the mathematical expression: $\mathrm{Yt}=\mathrm{Y}_{\max }\left[\mathrm{t} /\left(\mathrm{K}_{\mathrm{m}}+\mathrm{t}\right)\right]$ and to its linearized inverse: $1 / \mathrm{Y}_{\mathrm{t}}=\left(\mathrm{K}_{\mathrm{m}} / \mathrm{Y}_{\max }\right)(1 / \mathrm{t})+1 / \mathrm{Y}_{\max }$. We obtain a line allowing to calculate $Y_{\max }$ and $K_{m}$, knowing that $Y_{\max }$ were the yield at $t$ $=\infty$ (end of the extraction process) and $K_{m} / Y_{\max }$ : slope of the line and that the yield $\mathrm{Y}_{\mathrm{t}}$ is expressed in $\mathrm{g}$ of essential oil extracted/100 $\mathrm{g}$ of sample [22].

Langmuir's gas adsorption isotherm model is mathematically expressed by the equation: $Y_{t}=Y_{\max } \cdot t /(b+t)$ with $\mathrm{Y}_{\mathrm{t}}=$ yield at time $\mathrm{t}$; $\mathrm{Y}_{\max }$, the yield at $\mathrm{t}=\infty$ and $\mathrm{b} / \mathrm{Y}_{\max }$, the slope of the curve at the initial instants. The opposite form: $1 / Y_{t}=\left(/ Y_{\max }\right)(1 / t)+1 / Y_{\max }$ gives a straight line with a slope $=\mathrm{b} / \mathrm{Y}_{\max }$ and an ordinate at the origin $1 / \mathrm{Y}_{\max }[27]$.

The linear form of Monod's model equation (figure $4, \mathrm{R}^{2}=$ 0.9904) makes it possible to graphically determine the parameters of the model $\mathrm{Y}_{\max }=1 / 0.3021=3.31 \%$ and $\mathrm{K}_{\mathrm{m}}$ $/ \mathrm{Y}_{\max }=3.6083, \mathrm{~K}_{\mathrm{m}}=11.9440 \mathrm{~min} . \%^{-1}$. With $\mathrm{Y}_{\max }=3.31 \%$ $(t=\infty)$, the value of 3.01 assumed for $Y_{\max }$ corresponds to $(3.01 / 3.31) 100=91 \%$ for the extraction rate at 150 minutes. The Langmuir model leads to the same value of $\mathrm{Y}_{\max }: 3.31 \%$ and the same value of $\mathrm{b}=11.9440 \mathrm{~min} . \%^{-1}$ and identifiable at $\mathrm{K}_{\mathrm{m}}$.

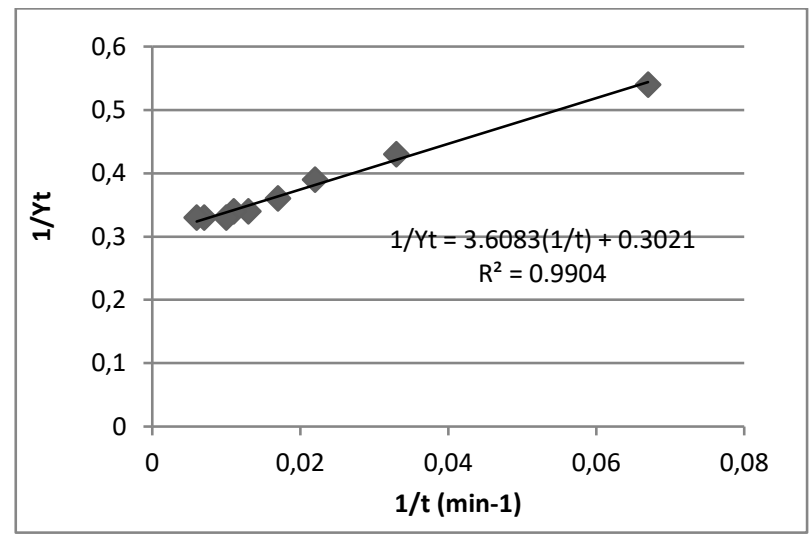

Fig. 4. Test straight line for Monod and Langmuir models for extraction essential oil from the fruits of Xylopia aethiopica.

\section{CONCLUSION}

The extraction of essential oil from Xylopia aethiopica fruits can be described by the phenomenological model in two steps according Sovova-Milojevic : a rapid washing of the oil located in the broken cells and at the solid-liquid interface of intact cells followed by a much slower step controlled by the oil diffusion from the inside to the outside of the intact cells of the plant matrix. Assuming the absence of the washing step, the process run to a pseudo first-order mechanism characterized by a kinetic constant $\mathrm{k}=0.0476 \mathrm{~min}^{-1}$ (Milojevic model). Assuming an instantaneous washing step, the process run to a second-order mechanism (Peleg model) characterized by a Peleg kinetic constant $\mathrm{K}_{1}=3,214 \mathrm{~min} \%^{-1}$ and a Peleg extraction capacity constant $\mathrm{K}_{2}=0,309 \%^{-1}$ from which the hydrodistilation kinetic constant $\mathrm{k}=\mathrm{K}_{2} / \mathrm{K}_{1}=0.0961 \mathrm{~min}^{-1}$ can be deduced. The models of Monod and Langmuir are also validated by kinetics of order 2 are also of possible reading grid of the experimental data relating to the extraction of essential oil from the fruits of Xylopia aethiopica.

\section{REFERENCES}

[1] Burkill H.M. The useful plants of west tropical Africa, second edition, Volume 1. Royal Botanic Gardens, Kew, 960 p, 1985.

[2] Johnson D.M, Murray A.N. A revision of Xylopia L. (Annonaceae): the species of Tropical Africa PhytoKeys 97: 1-252, 2018.

[3] Aubreville, A., La flore forestiere de la Côte d'Ivoire. Tome I. CTFT, 369p, 1959.

[4] Tchiegang, C. and P.D. Mbougueng, Composition chimique des épices utilisées dans la préparation du Nah-poh et du Nkui de l'Ouest Cameroun. Tropicultura, 23: 193-200, 2005.

[5] Letouzey, R., Manuel de botanique forestière. Afrique Tropicale. Tome 2. CTFT Nogent-sur- Marne, pp: 134, 1982.

[6] Tisserant P. Ch., Catalogue de la flore de l'Oubangui-Chari. Mémoire de l'Institut d'études centrafricaines, 2: 20, 1950.

[7] Fekam, B.F., Ngouana V., Amvam Z.P.H., Menut C., Bessiere J.M., Gut J. and Rosenthale P.J., Composition and anti-plasmodial activities of essential oils from some Cameroonian medicinal plants. Phytochemistry, 64: 1269-127, 2003.

[8] Anvam, Z.P.H., Extraction et analyse des huiles essentielles de trois espèces de la famille des annonacées du cameroun. Faculté des Sciences, Yaoundé. pp: 27, 1998.

[9] Neuenschwander P, Sinsin B, Goergen G. Protection de la Nature en Afrique de l'Ouest: Une Liste Rouge pour le Bénin. Nature Conservation in West Africa: Red List for Benin. Ibadan: International Institute of Tropical Agriculture; 2011.

[10] Ganglo C, Dan C., Aoudji A.K. N., Gbetoho A. J., Ganglo J.C., Importance Socio-Économique De Xylopia Aethiopica (Dun) A. Rich. Pour Les Populations Du Sud-Bénin European Scientific Journal November edition Vol.13, No.33 187-201, 2017.

[11] Kama Niamayoua R., Silou T., Bassiloua J.B., Diabangouaya M., Loumouamou A.N and Chalchat J.C., Characterisation of Essential Oils of Xylopia aethiopica (Dunal) A. Rich for Afforestation of the Coastal Savanna at Pointe-Noire (Congo-Brazzaville), Advance Journal of Food Science and Technology 6:728-736, 2014.

[12] Angiosperm Phylogeny Group III (APG III), An update of The Angiosperm Phylogeny Group classification for the orders and families of flowering plants: APG III. Botanical Journal of the Linnean Society161(2):105-121, 2009.

[13] Chinedu I., Ojochenemi E. Yakubu1, Nkeiruka G.I., Ifeoma Sandra Udegbunam3, Ogochukwu J., Onukwugha1, Chemical composition of Xylopia aethiopica fruits American journal of physiology, biochemistry and pharmacology, 7 (2): 48-53, 2018.

[14] Adams R.P., Identification of essential oils by capillary gas chromatography/mass spectroscopy. Allured, Carol stream, IL. 1001, 2012.

[15] McLafferty F.W. and Stauffer D.B., The Wiley/NBS Registry of Mass Spectral Data. John Wiley and Son, New York, NY, 1989.

[16] Bucic-Kojic A.., Mirela P., Srecko T., Mate B., and Darko V., Study of solid-liquid extraction kinetics of total polyphenols from grape seeds. Journal of Food Engineering, 81: 236-242, 2007.

[17] Milojevic S.Z., STojanovic T.D., Paliv R., Lazic M.L.and VeljkovicV.B., Kinetics of distillation of essential oil from comminuted ripe Jupiter (Juniperus communis L.) berries, Biochemical Engineering Journal, 39: 547-553, 2008.

[18] Milojevic S.Z., Radosavljevic D.B., Pavicevic V.P., Pejanov S., Veljkovic V.B., Modeling the kinetics of essential oils from plant materials. Hem. Ind: 843-850, 2013.

[19] Meziane IAA, Bali N, Belblidia NB, Abatzoglou N, Benyoussef E-H. The first-order model in the simulation of essential oil extraction kinetics, Journal of Applied Research on Medicinal and Aromatic Plants. 2019. doi: https://doi.org/10.1016/j.jarmap.2019.100226.

[20] Sovova H., Aleksovski S.A., Mathematical model for hydrodidtillayion of essential oils. Flavour and Fragrance Journal, 21: 881-889, 2006.

[21] Peleg M. An Empirical model for description of moisture sorption curves. Journal of Food Science, 53 (4): 1216- 1219, 1988.

[22] Mjeri J., Chakroun I., Abderraba M., Mejri M., Study of hydrodistillation process of Ruta chalpensis L essential Oil. Research Journal of Agriculture and Environmental Mangement. 3 (4): 311-518, 2014.

[23] Amenaghawon N.A., Okhueleigbe K.E., Ogbeide S.E. and Okieimen C.O. Modelling the kinetics of steam distillation of essential oils from lemon grass (Cymbopogon spp) International Journal of Applied Science and Engineering, 12 (2): 107-115, 2014. 
[24] Thanh N.D.B., Duc T.H., Dung N.T., Kinetics and modeling of oil extraction from vietnam lemongrass by steam distillation Vietnam Journal of Science and Technology 55 (5A) 58-65, 2017.

[25] Sepidar S., Zurina Z.A., Robiah Y. and Azhari M? Extraction of Oil from Jatropha Seeds-Optimization and Kinetics. American Journal of Applied Sciences 6. 6(7):1390-1395, 2009.

[26] So GC, Macdonald. Kinetics of oil extraction from canola (rapeseed). Can J. Eng., 64: 80-86, 1986.

[27] Babu G.D.K., Singh B., Simulation of Eucalyptus cinerea oil distillation: A study on optimization of 1,8 - cineole production. Biochem. Eng. J., 44: 226 - 231, 2009.

[28] Shafaei S.M., Masoumi A.A., Roshan H., Analysis of water adsorption of bean etchickpea during soaking using Peleg model. Journal of the Saudi Society of Agriculture Sciences 15: 135 - 144, 2016,

[29] Patricelli A., Assogna A., Casalaina A., Emmi E, Sodini G. Fattori che influenzano l'estrazione dei lipidi da semi decorticati di girasole. Riv. Ital. Sostanze Grasse, 56 :136-142, 1979.

[30] Yapi T. A., Boti J. B., Tonzibo Z.F., Ahibo C. A., Bighelli A., Casanova J., Tomi F., Combined analysis of Xylopia aethiopica trunk bark oil by chromatographic and spectroscopic techniques. American Journal of Essential Oils and Natural Products; 2 (1): 11-14, 2014.

[31] Tomi F., Casanova J. \& Nianga M. Identification of the seed oil of Xylopia aethiopica from Guinea using ${ }^{13} \mathrm{C}-\mathrm{NMR}$ spectroscopy. Journal of Essential Oil Research, 8: 429-431, 1996.

[32] Ayedoun M.A., Moudachirou M., Tomi F. et Casanova J., Identification par RMN du carbone--13 et CPG/SM des principaux constituants des huiles essentielles des feuilles de Xylopia aethloplca (Dunal). Richard et de Commiphora africana (A. RICH.) ENGL. du Bénin, J. SOACHIM, 3: 29-35, 1997.

[33] Jirovetz L., Buchbauer G., Ngassoum MB. Investigation of the essential oils from the dried fruits of Xylopia aethiopica (West African "peppertree") and Xylopia parvifl ora from Cameroon. Ernahrung 21 (7-8), 324-325, 1997.

[34] Poitou F., Masotti V., Guigues de Souza S., Viano J., Gaydou M., Composition of the essential oil of Xylopia aethiopica dried fruits from Benin. J. Essent. Oil Res. 8 (3), 329-330, 1996.

[35] Karawya MS., Abdel SM., Hifnawy MS.). Essential oil of Xylopia aethiopica fruit. Planta Med. 37, 57-59, 1979.

[36] Noudjou, F., H. Kouninki, T. Hance, E. Haubruge, S.T.N. Léonard, M.M. Pierre et al., Composition of Xylopia aethiopica (Dunal) A. Rich essential oils from Cameroon and identification of a minor diterpene: ent-13-epi manoyl oxide. Biotechnol. Agron. Soc., 11:193-199, 2007.

[37] Nguemtchouin Mbouga M. G., Formulation d'insecticides en poudre par adsorption des huiles essentielles de Xylopia aethiopica et de Ocimum gratissimum sur des argiles camerounaises modifiées. Thèse de Doctorat en cotutelle Universités Ngaoundéré/ Montpellier 2012.

[38] Ogunwande I. A. , Olawore N.O. \& Kasali A.A., Contribution to the Study of Essential Oil of Xylopia Aethiopica (DUNAL) A. RICH: Isolation and Characterization of Zerumbone Journal of Essential Oil Bearing Plants, Volume 8, Issue 2, 2005, Published online: 12 Mar 2013.

[39] T. Silou, J. Matoko, C. A. Baou, K. Taba, J. C. Chalchat, G. Figueredo. Kinetic modeling of hydrodistillation of Ocimum basilicum essential oil from the "plateau des Cataractes" (Congo Basin). Journal of Essential Oils and natural Products. Accepted for publication. Octobre 2020.

[40] Desai M. A., Parikh J., De A. K. - Modelling and optimization studies on extraction of lemongrass oil from Cymbopogon flexuosus (Steud.) Wats. Chemical Engineering Research and Design, 92: 793-803.

[41] Silou T., Bitemou E., Bikindou K., Loumouamoua A.N., Chalard P. Aromatic Plants from "Plateau des Cataractes": Kinetic modeling of the extraction of leaf essential oils from Curcuma mangga (Valeton \& Zijp) acclimatized in Congo-Brazzaville, unpublished, 2021.

[42] Farhana E.N., Lutfi N.A., Atan F.M., Rahman N.A., Salleh S.F., Wahab N.A., Study on distillation. Journal of Applied Sciences \& Process Engineering, 3 (1): 1-16, 2016.

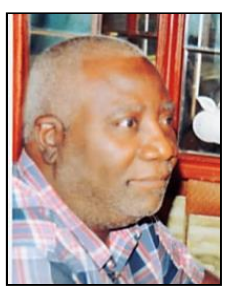

Thomas Silou was born in 1951, Republic of Congo.

Academic records: PhD (University of Orleans, France), Post Doc (University of Montpellier II, France; University of Louvain-La-Neuve, Belgium, University of Montreal, Canada) Food chemistry and technology, Organic physical Chemistry, Research Evaluation. Academic positions: He worked as Assistant Lecturer, Lecturer, and Full Professor at University Marien Ngouabi, Brazzaville in Chemistry, Biochemistry, Food Engineering. He became Emeritus Professor in 2016 after serving in various positions including: Head of Department of Chemistry, Head of Industrial and Technological Sciences Section, Department of Education, President of the Commission in charge of the Scientific and Cultural Affairs, President of the Commission of Scientific Evaluation, Faculty of Science, Brazzaville, Congo.

Scientific production: During 40 teaching and Research years at different Universities in Africa, France and Belgium, He supervised 30 $\mathrm{PhD}$ thesis, published 6 books and book chapters and 150 original scientific articles in international journals (cf Reasearch Gate/Linked In). Reviewer: Journal of Essential Oil Research (USA), Flavour and Fragrance Journal (Swiss), Journal of Essential oil Plant Bearing (India)) Revista Italiana Sostanze Grasse (Italy), LWT: Food Science and Technology, Elsevier (Swiss) and Member of Boards: Oilseeds Crops and Lipids (OCL) Journal (France), American Journal of Essential oil and Natural Products (USA). Awards and honors: Academic Palms (CAMES), Ordre de Mérite Congolais (Officier) Republic of Congo, and Ordre de Mérite Agricole (Chevalier) Republic of Congo.

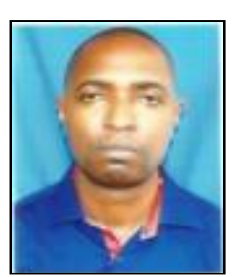

Jean Bruno Bassiloua was born in 1976, Republic of Congo. Academic records: Rural Development Engineer, Diploma of Advanced Studies (DEA), PhD (Marien Ngouabi University, Brazzaville), Mineral Nutrition of Plants in Forestry, Symbiotic Fixation of Atmospheric Nitrogen of Leguminous Plants, Chemistry and Food Technology. Academic positions: He worked as Assistant Lecturer, at University Marien Ngouabi, Brazzaville in Chemistry and Food Technology, Ecochemistry, Environmental Chemistry. As Assistant at the Higher School of Technology "Les Catarctes" (ESTc), Brazzaville, in Physiology of Plant Nutrition, Agroforestry. Scientific production: during 5 research years and 3 teaching years in research centers in Congo (Research Unit on the Productivity of Industrial Plantations (UR2PI), Center de Recherches Forestières du Littoral (CRFL)), at the University Marien Ngouabi and in France (CIRAD), He published 1 engineering thesis, 1 DEA thesis, $1 \mathrm{PhD}$ thesis, supervised 3 dissertations and published 4 original articles in international journals. Reviewer: International Journal of Biological and Chemical Sciences, Advance Journal of Food Science and Technology; Journal of Animal and Plant Sciences. Research Grant: International Found for Sciences (IFS); CIRAD. Jobs: Program Manager at the Coastal Forestry Research Center (CRFL), Head of the Production and Processing, Department of Essential Oils (Center for the Valorization of Non-Wood Forest Products (CVPFNL) of the Ministry of Forest Economy. 